\title{
A Probit Analysis of Factors Affecting Improved Technologies Dis-adoption in Cocoa-Based Farming Systems of Southwestern Nigeria
}

\author{
Kehinde A. D., Adeyemo R. \\ Department of Agricultural Economics, Obafemi Awolowo University, Ile Ife, Nigeria \\ Email address: \\ kehindeayodeji8@gmail.com (Kehinde A. D.)
}

\section{To cite this article:}

Kehinde A. D., Adeyemo R. A Probit Analysis of Factors Affecting Improved Technologies Dis-adoption in Cocoa-Based Farming Systems of Southwestern Nigeria. International Journal of Agricultural Economics. Vol. 2, No. 2, 2017, pp. 35-41. doi: 10.11648/j.ijae.20170202.12

Received: February 16, 2017; Accepted: March 8, 2017; Published: March 25, 2017

\begin{abstract}
Increasing productivity via continuous use of improved technologies remains a viable strategy to reducing food insecurity and poverty among smallholder farmers. These improved technologies include improved seed varieties, fertilizer, recommended spacing, recommended mixed cropping and pesticides. This study investigated dis-adoption of improved technologies among farmers in cocoa-based farming systems of Southwestern Nigeria. A multistage sampling procedure was used to obtain information from 200 respondents. Data were analyzed using descriptive statistics and probit regression model. Descriptive statistics revealed that $7.5 \%$ of the respondents did not adopt any improved technologies. About 51.0\%, 35.0\%, $36.5 \%, 69.0 \%$, and $53.5 \%$ of the respondents previously adopted improved seed varieties, fertilizer, recommended spacing, recommended mixed cropping, and pesticide respectively. However, about $28.4 \%, 68.6 \%, 36.4 \%, 58.9 \%$, and $29.0 \%$ of the respondents discontinued improved seed varieties, fertilizer, pesticide, the recommended spacing, and recommended mixed cropping, respectively. Probit estimates revealed that factors affecting dis-adoption of improved technologies were membership of an association $(\mathrm{P}<0.01)$, years of formal education $(\mathrm{P}<0.05)$, access to credit $(\mathrm{P}<0.05)$, farm size $(\mathrm{P}<0.01)$, household size $(\mathrm{P}<0.01)$, gender $(\mathrm{p}<0.1)$ and contact with extension agent $(\mathrm{p}<0.01)$. Increasing the uptake of improved technologies could be achieved through enlightenment programmes by effective and efficient extension services during farmer field days. Also, farmers should be encouraged to form farmers' organizations in the study area to improve their access to basic resources such as credit.
\end{abstract}

Keywords: Probit, Technologies, Dis-Adoption, Cocoa-Based Farming, Southwestern

\section{Introduction}

Cocoa economy vastly contributed to economic development of Nigeria. This sector contributed up to $15 \%$ of Nigerian export in 1970's [1]. The contribution of cocoa before the advent of crude oil in 1970's was appreciably substantial [2]. With respect to foreign exchange earnings and employment, cocoa (Theobroma Cacao) has earned exchange and employed a lot of people directly and even indirectly more than other commodities. In addition, it is an important source of raw materials, as well as source of revenue to cocoa producing states.

However, cocoa production has been declining after 1970 's season reducing nation's share to about $6 \%$ and to fifth largest producer till date [2]. This is sequel to low productivity level of smallholder farmers on individual farms therefore placing them in severe poverty status [3]. Contributing factors are identified as disease and pest attack, poor production pattern, non-use of improved technologies and management practices among others $[4,5]$.

Many strategies were attempted to increasing cocoa production in Nigeria especially Southwest. These include dissemination of recommended technologies to cocoa farmers for adoption among other attempts. Agricultural research institutes all over the country in collaborative efforts with the universities have generated a lot of improved technologies consistent with sustainable natural resource management [6].

Despite this effort, productivity in cocoa based farming systems remained abysmally low [7]. This could be traced to low rate of adoption of improved technologies [8, 9]. Consequently, smallholder farmers obtain yields lower than 
potential yields. Several scholars have investigated factors affecting adoption rate of improved technologies [10, 11, 12, 13]. Only few have investigated dis-adoption of technologies $[14,15,16,17]$.

However, continuous use of improved technologies is inevitable in the efforts of agricultural development [18]. Dis-adoption is one of the important factors that thwarts efforts geared towards achieving agricultural development. Technology dis-adoption has been ignored over time, even though, technologies dis-adopted are ineffective as technologies not adopted [19]. This necessitates that farmer's decision on technology adoption has to be monitored [20]. This will guide all efforts aimed at increasing productivity through improved technologies. However, investigating into dis-adoption parameters would reveal the reasons behind rejection of the previously adopted technologies.

There are two main reasons accounting for agricultural technologies dis-adoption [21]. These include replacement discontinuance, when a farmer discontinue a technology to adopt a superior technology, and disenchantment discontinuance, where a farmer discontinue a technology with or without replacement due to dissatisfaction of the technology performance [21]. Hence, this paper focuses on the dis-adoption of improved technologies in cocoa-based farming systems of southwestern Nigeria. Specifically, determines the previous adoption level of technologies among cocoa farmers, profiles the different technologies in continuous use and those abandoned with reasons; and determines the factors affecting technologies dis-adoption among cocoa farmers.

\section{Methodology}

\subsection{Study Area}

The area of study is Southwestern Nigeria. It is situated in the tropical rain forest zone. It covers an area of approximately $14,875 \mathrm{sq} \mathrm{km}$ and lies between latitude $7^{\circ} 30^{\prime} 0^{\prime \prime} \mathrm{N}$ and longitude $4^{\circ} 30^{\prime} 0^{\prime \prime} \mathrm{E}$. The dry season lasts from November to March while the wet season starts from April and ends in October. Average daily temperature ranges between $25^{\circ} \mathrm{C}\left(77.0^{\circ} \mathrm{F}\right)$ and $35^{\circ} \mathrm{C}\left(95.0^{\circ} \mathrm{F}\right)$, almost throughout the year. Though a landlocked region, it is blessed with presence of many rivers and streams which serves the water needs of the zone. The Climate is equatorial, notably with dry and wet seasons with relatively high humidity. The favourable climate of the area encouraged about 70 percent of the inhabitants to engage in farming. They grow both permanent and food crops. The farmers are predominantly small scale. The climate is ideal for the cultivation of crops like cocoa, maize, yam, cassava, millet, rice, plantain and cashew. Two States namely, Oyo and Osun States in Southwestern Nigeria constitute the study area.

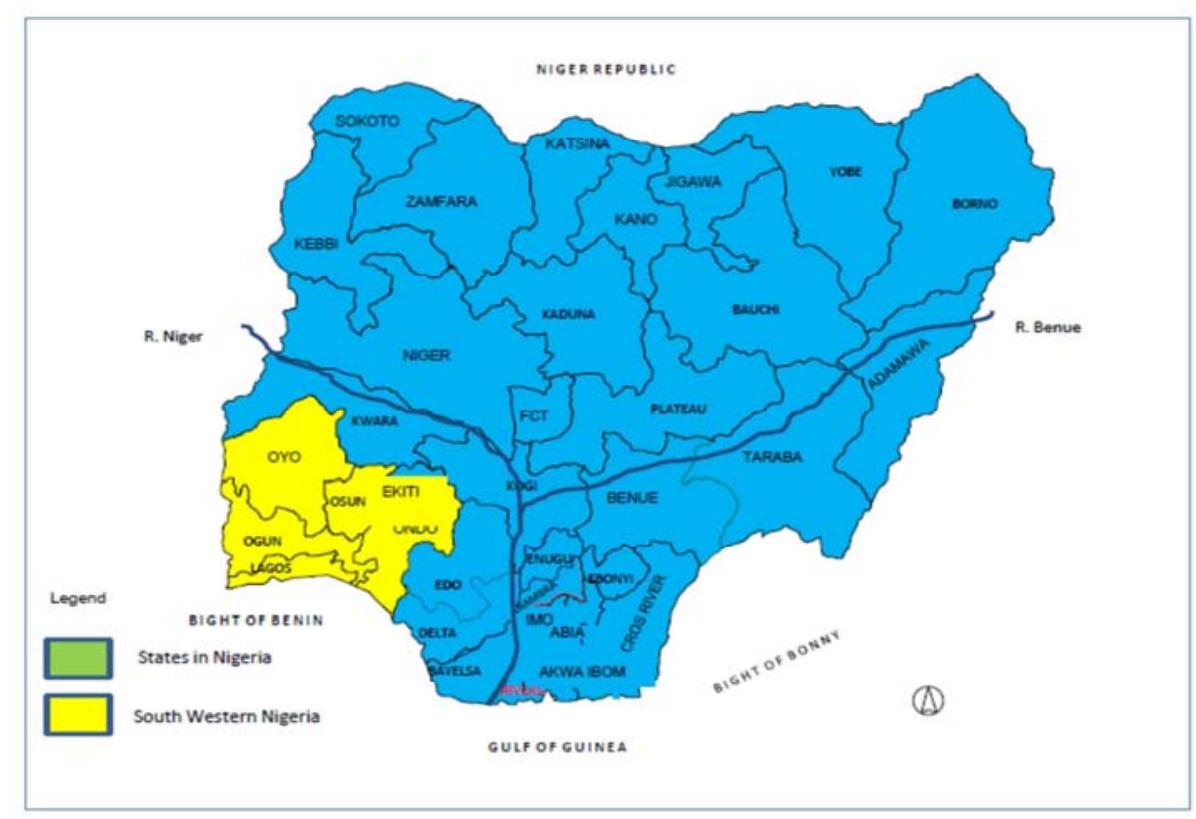

Figure 1. Map of Nigeria Showing the Study Area.

\subsection{Sampling Procedure and Sample Size}

A multistage sampling procedure was employed to obtain data for the study. The first stage involved the random selection of two States in Southwestern Nigeria (Osun and Oyo States). The second stage was the purposive selection of two Local Government Areas (LGAs) in each State. Ido and Ogo-oluwa LGAs were selected in Oyo State, while
Atakumosa East and Ayedire LGAs were selected in Osun State. The selection was based on the predominance of cocoa farmers in the LGAs. The third stage was the simple random selection of five villages from the list of cocoa growing villages in each of the four LGAs. The fourth stage involved the simple random selection of ten cocoa farming household in each village making a total sample of 200 cocoa farmers for the study. 


\subsection{Analytical Technique}

\subsubsection{Descriptive Analysis}

Descriptive statistics (percentages) was used to determine the previous adoption level of technologies among cocoa farmers and to profile the different technologies in continuous use and those abandoned with reasons.

\section{$\mathrm{Y}_{\mathrm{i}}=\beta_{0}+\beta_{1}$ AGEHHED $+\beta_{2}$ FFEDU $+\beta_{3}$ FAMEXP $+\beta_{4}$ HHSIZE $+\beta_{5}$ MEMBASS $+\beta_{6}$ ACCREDIT $+\beta_{7}$ GENHHED $+\beta_{8}$ FAMSIZE $+\beta_{9}$ EX} TENSN $+\mathrm{e}_{i}$

Where,

$\mathrm{Y}$ is the dependent variable, the probability of technologies dis-adoption (Dummy: 1, discontinued; 0, otherwise).

The definitions of independent variables are AGEHHED is age of the farmers (years), FFEDU is number of years of formal education (years), FAMEXP is year of farming experience (years), HHSIZE is household size (\#), MEMBASS is membership of association (dummy variable $0=$ non-member, $1=$ member $)$ ACCREDIT is access to credit ( $1=$ accessible, $0=$ inaccessible), GENHHED is gender of house hold head $(0=$ female, $1=$ male $)$, FAMSIZE is farm size (ha), EXTENSN is extension visit $\left(1=\right.$ yes, $0=$ no), and $\mathrm{e}_{\mathrm{i}}$ is random error term.

The marginal effect of the variables is calculated using the formula:

\section{Marginal effects $=B_{i} \varnothing(Z)$}

Where $\mathrm{B} i$ are the coefficients of the variables and $\varnothing(\mathrm{Z})$ are the cumulative normal distribution value associated with the mean dependent variable from the probit estimation.

The rationale behind the inclusion of these variables in the model was based on a prior expectation on the variable used. These explanatory variables are expected to influence the disadoption of improved technologies. Age has influence on disadoption of improved technologies. It is generally considered that older people have more farming experience that helps them to continue with the use of improved technologies. Educational status of the farmers is assumed to have positive influence on continued use of agricultural technologies because its ability to obtain process, understand and interpret the agricultural information coming to farmers from any direction [23, 24]. It is hypothesized that education is negatively related to dis-adoption.

Land tenure measured as dummy (1, if owned and 0 , otherwise). It is hypothesized that land-tenure status is positively related to continued use of improved technologies. Farmers who rent farmland may be less likely to invest in new technologies. This may be due to the perceived insecurity of the tenancy [25].

Experience of the farmer influences continued adoption of improved technologies. A more experienced farmer may have a lower level of uncertainty about the improved technology's performance [26]. Household size is the number of persons that pool resource together, live under the same roof and eat from the same pot related by blood or not. A

\subsubsection{Probit Analysis}

Probit regression model was used to determine the factors affecting dis-adoption of improved technologies among cocoa farmers in the study area. This model was employed because it accommodates two categories in the dependent variable. It has ability to resolve the problem of heteroscedasticity and it satisfies the assumption of cumulative normal probability distribution [22].

large household size working on the farm reduces the expenditure on hired labour. Hence, it is assumed to positively affect decision to adopt improved technologies [27]. Membership of association such as cooperatives society discourage dis-adoption of new technologies. Membership of social group is a measure of social capital. Farmers who are not members of associations are expected to dis-adopt improved technologies. Access to credit was measured as a dichotomous variable with access being one, and zero for no access. It is expected to discourage dis-adoption of technologies positively [28].

Gender is one of the factors influencing continuation of new technologies. In adoption studies, gender is a controversial factor. Male farmers have enough freedom to participate in different meetings therefore they have access to information concerning improved technologies [29]. Farm size has positive effect on adoption of most technologies. However, the larger the farm size the greater the likelihood that a farmer will invest in improved technologies. The size of the land will positively affect the decision to uptake improved production technologies [30]. Extension visit implies easy exposure to new technologies. Therefore, extension contact is expected to have a positive influence on farmer's adoption of improved technologies. It is believed that frequent contacts will enhance the exposure of farmers to improved production package and discourage dis-adoption [28].

Table 1. Description of variables.

\begin{tabular}{lll}
\hline Variables & Units & Expected signs \\
\hline Age & Years & \pm \\
Education & Formal education $=1$ & \pm \\
Land Tenure Status & Informal=0 & \pm \\
Farming experience & Access; yes $=1$, no $=0$ & \pm \\
Farm house hold size & Years & \pm \\
Extension visit & Number of members & \pm \\
Membership of association & Yes=1, No=0 & - \\
Access to Credit & member=1, Non- & - \\
Farm size & Access; yes=1, no=0 & - \\
Gender of House hold Head & Female $=0$, Male $=1$ & \pm \\
\hline
\end{tabular}

\section{Results and Discussion}

\subsection{Previous Adoption Level of Improved Technologies}

Figure 2 reveals previous adoption level of improved 
technologies in cocoa-based farming systems. Only $7.5 \%$ of the respondents did not adopt any improved technologies. About $51.0 \%, 35.0 \%, 36.5 \%, 69.0 \%$, and $53.5 \%$ of the respondents previously adopted improved seed varieties, fertilizer, recommended spacing, recommended mixed cropping, and pesticide respectively. This study implies that high adoption rate of the improved seed could be ascribed to its availability which consequently aids the timely planting of the seed. The adoption of recommended mixed cropping could be attributed to environmental and economic benefit associated with the technology, while that of pesticide might be associated with effective performance of the technology in controlling cocoa pest. The study further implies that the non-adoption of fertilizer could be as a result of the high cost associated with this technology, while that of the recommended spacing could be as a result of the technicalities involved in the recommended technology. The presence of non- adopters could be sequel to poor information and lack of encouragement from the concerned agricultural organizations [30].

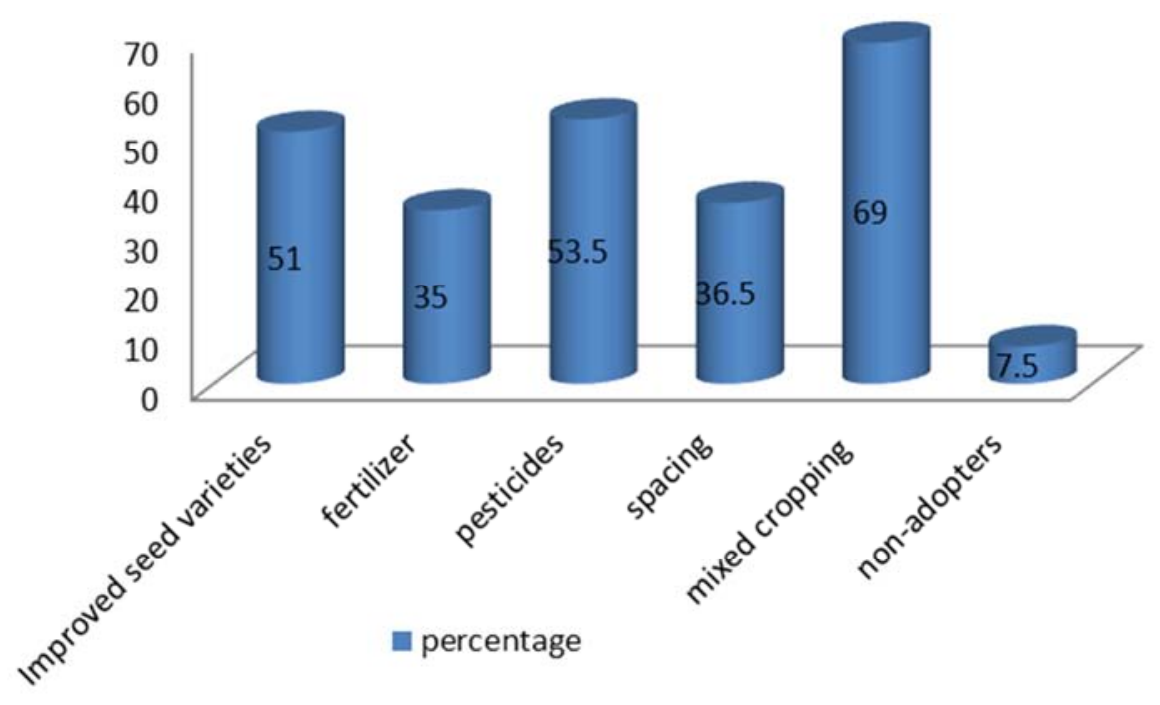

Source: Field Survey, 2015.

Figure 2. Previous adoption level of improved technologies.

\subsection{Profile of Technologies in Continuous Use or Abandoned}

The profile of technologies in continuous use or abandoned were presented in Figure 3. About 28.4\%, 68.6\%, $58.9 \%, 29.0 \%$, and $36.4 \%$ of the respondents discontinued improved seed varieties, fertilizer, recommended spacing, recommended mixed cropping, and pesticide, respectively. The study implies majority of the respondents: $68.6 \%$ and $58.9 \%$ abandoned the use of fertilizer and recommended spacing, respectively. However, the farmers in the study area discontinued these technologies without replacement.

\section{Disadoption rate of improved technologies}

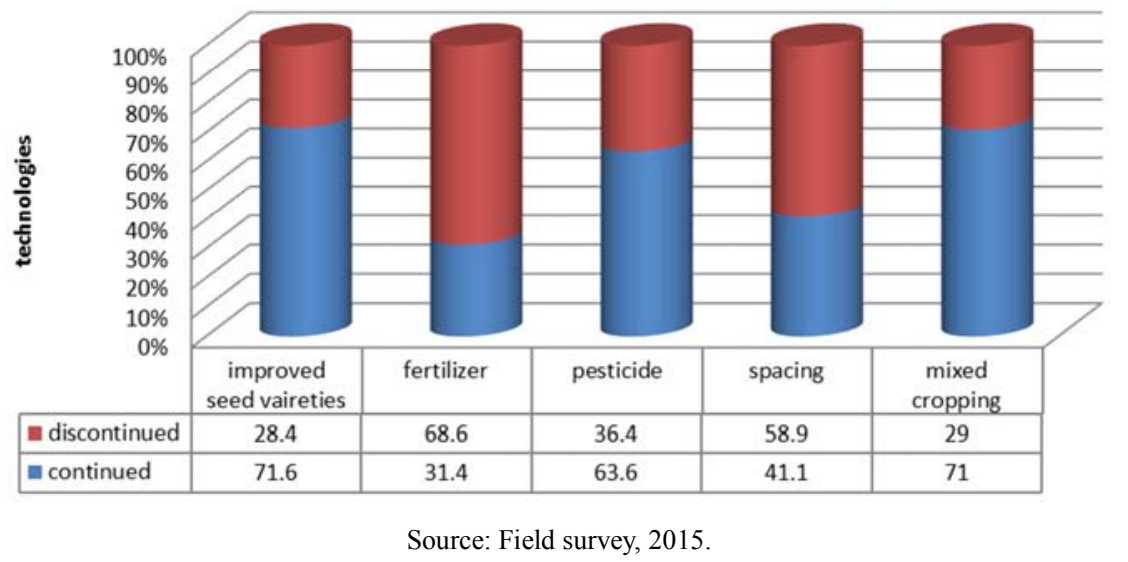

Figure 3. Dis-adoption rate of improved technologies.

\subsection{Reasons for Abandonment of Improved Technologies}

The reasons for abandonment of improved technologies were presented in Table 2. About $65.5 \%$ of the respondents abandoned improved seed varieties based on financial constraint, and $34.5 \%$ based on insufficient land available for 
farming. About $62.5 \%$ of the respondents abandoned fertilizer based on its poor performance (destroys cocoa farm), and $34.5 \%$ based on high cost associated with the technology. About $64.1 \%$ of the respondents abandoned the use of pesticide based on high cost associated with the technologies and $35.9 \%$ of them said it was due to poor performance of the technology (ineffectiveness in controlling cocoa pest). However, $67.4 \%$ of the respondents abandoned the use of recommended spacing was due to technicality involved in the recommended technology, while $27.9 \%$ of them said it was a waste of time, and $4.7 \%$ of them said it was necessary. About $35.0 \%$ of the respondents abandoned the use of recommended mixed cropping due to financial constraint, but $20.0 \%$ of them said it was due to the technology failure, and $45.0 \%$ of them said it was due to insufficient land for farming. The farmers in the study area discontinued most of these technologies without replacement due to financial constraint, insufficient farm land and poor performance. This follows Roger's disenchantment theory of discontinuance [21].

Table 2. Reasons for discontinuance of improved technologies.

\begin{tabular}{lll}
\hline Reasons for discontinuance & Frequency & Percentage \\
\hline Improved seed varieties & & \\
Financial constraint & 19 & 65.5 \\
Insufficient land & 10 & 34.5 \\
Total & 29 & 100 \\
Fertilizer & & \\
Poor performance & 30 & 62.5 \\
High cost fertilizer & 18 & 37.5 \\
Total & 48 & 100 \\
Pesticide & & \\
High cost of pesticide & 25 & 64.1 \\
Poor performance & 14 & 35.9 \\
Total & 39 & 100 \\
Spacing & & \\
Technicality & 29 & 67.4 \\
Waste of time & 12 & 27.9 \\
No need & 2 & 4.7 \\
Total & 43 & 100.0 \\
Mixed cropping & & \\
Financial constraint & 14 & 35 \\
Failed germination & 8 & 20 \\
Insufficient land & 18 & 45 \\
Total & 40 & 100.0 \\
\hline
\end{tabular}

\subsection{Determinants of Dis-adoption of Improved Technologies}

The factors influencing farmers' dis-adoption of each of the improved technologies were presented in Table 3. From Table 3, household size $(\mathrm{p}<0.01)$, membership of an association $(p<0.01)$, and gender $(p<0.1)$ significantly influenced the dis-adoption of improved seed varieties. The coefficients of membership of an association and gender had negative signs. This implies that for every unit decrease in any of these variables, the rate of dis-adoption increases by the magnitude of their coefficients; 0.405 and 0.557 units for gender and membership of association respectively. However, coefficient of household size was positive. This implies that for every unit increase in household size, the rate of dis-adoption increases by 0.558 units. For pesticide, gender $(p<0.1)$, membership of an association $(p<0.01)$, access to credit $(p<0.05)$ and farm size $(p<0.01)$ significantly influenced its dis-adoption. However, the coefficients of membership of an association, access to credit and gender had negative signs. This implies that for every unit decrease in any of these variables, the rate of dis-adoption increases by the magnitude of their coefficients; $1.295,0.335$ and 0.645 units for access to credit, gender and membership of association respectively. On the other hand, coefficient of farm size was positive. This implies that for every unit increase in farm size, the rate of dis-adoption increases by 0.041 units. Specific to fertilizer, farm size $(p<0.01)$ positively influenced its adoption. This implies that increase in farmers' farm size increase the rate of dis-adoption of fertilizer by 0.031 units. Similarly, contact with extension agent $(p<0.05)$ negatively and significantly influenced the dis-adoption of recommended mixed cropping. This implies that for every unit decrease in this variable, the rate of disadoption increases by 0.147 units. Gender $(p<0.01)$ and years of formal education $(p<0.05)$ significantly influenced disadoption rate of recommended spacing. The coefficients of these variables were negative. This implies that an effective contact with male farmers decreases the rate of dis-adoption. Similarly, an increase in years of formal education decreases the dis-adoption rate by 0.006 units.

Source: Field Survey, 2015.

Table 3. Factors influencing the dis-adoption of improved technologies.

\begin{tabular}{|c|c|c|c|c|c|}
\hline Variables & Improved seed varieties & Pesticides & Fertilizer & Mixed cropping & Spacing \\
\hline Age & $0.002(0.28)$ & $-0.008(-0.10)$ & $0.003(0.32)$ & $-0.004(-0.49)$ & $-0.009(-1.07)$ \\
\hline Years of formal education & $0.015(0.71)$ & $0.017(0.81)$ & $0.002(0.14)$ & $0.007(0.30)$ & $-0.006(-2.29)$ \\
\hline Farming experience & $0.002(0.29)$ & $-0.0007(-0.90)$ & $0.004(0.57)$ & $0.005(0.65)$ & $-0.001(-02.3)$ \\
\hline Household size & $0.058(2.85)^{* * *}$ & $0.007(0.42)$ & $0.227(1.31)$ & $0.031(1.74)$ & $0.019(1.05)$ \\
\hline Membership of an association & $-0.557(-2.66)^{* * *}$ & $-0.649(-3.05)^{* * *}$ & $0.129(0.61)$ & $0.138(0.65)$ & $0.075(0.36)$ \\
\hline Access to credit & $-0.193(-0.35)$ & $-1.295(-2.13)^{* *}$ & $-0.078(-0.14)$ & $0.170(0.31)$ & $0.462(0.84)$ \\
\hline Gender & $-0.405(-1.70)^{*}$ & $-0.335(-1.71)^{*}$ & $0.065(0.27)$ & $-0.020(-0.09)$ & $0.648(2.80)^{* * *}$ \\
\hline Contact with extension agent & $0.106(1.46)$ & $0.075(0.10)$ & $0.039(0.54)$ & $-0.147(-1.98)^{* *}$ & $-0.098(-1.35)$ \\
\hline Log likelihood & -125.915 & -124.060 & -120.761 & -117.043 & -122.056 \\
\hline Chi square & 25.35 & 30.16 & 31.96 & 31.55 & 61.08 \\
\hline Prob $>$ chi 2 & 0.0047 & 0.0008 & 0.0054 & 0.0045 & 0.0098 \\
\hline
\end{tabular}

*** Significant at 1\%,** Significant at 5\%, * Significant at 10\%. Figures in parentheses () are t-values. Source: Field Survey, 2015 


\section{Conclusion}

Majority of farmers previously adopted the improved technologies under consideration. These includes improved seed varieties, fertilizer, recommended spacing, recommended mixed cropping, and pesticide. However, most of the farmers had stopped the use of fertilizer and recommended spacing in the study area. The farmers in the study area discontinued these technologies without replacement due to financial constraint, insufficient farm land and poor performance of the technologies. Probit estimates revealed that household size $(p<0.01)$ and membership of an association $(\mathrm{p}<0.01)$ were determinant of dis-adoption of improved seed varieties, membership of an association $(p<0.05)$, access to credit $(p<0.05)$, gender $(p<0.1)$, and farm size $(p<0.01)$ were determinants of dis-adoption of pesticides. However, farm size $(p<0.01)$, contact with extension agents $(\mathrm{p}<0.05)$, and gender $(\mathrm{p}<0.01)$ were specific determinants of dis-adoption of fertilizer, recommended mixed cropping, and recommended spacing, respectively. All the significant variables should be taken into consideration in efforts to reducing dis-adoption of improved technologies in cocoa-based farming systems. Increasing the uptake of improved technologies could be achieved through enlightenment programmes by efficient extension services during farmer field days. Also, farmers should be encouraged to form farmers' organizations in the study area to improving their access to formal credit and other productive resources.

\section{References}

[1] Adebile O. A and Amusan A. S (2011) The non- oil sector and the Nigeria Economy a case study of Cocoa Export since 1960" International Journal of Asian Social Science, 1 (5), 142-151.

[2] Folayan, J. A., Daramola, G. A. and Oguntade, A. E., (2006) Structure and performance evaluation of cocoa marketing institutions in South-Western Nigeria: An economic analysis. Journal of Food, Agriculture and Environment, 4(2), 123-128.

[3] Emokaro C. O. and Izekor, O. B. (2010) An econometric analysis of the effect of farming practices by arable crop farmers on environmental degradation. International journal of Agricultural Economics and Extension Services, 1 (Maiden Edition), 76-87.

[4] Food and. Agriculture Organization (FAO). 2003. Fishery intensification in small water bodies: a review of North America. FAO Fisheries Technical Paper no 33, Rome Italy.

[5] Nwachukwu, I., Ndubuto, N. A., Jude, N. and George, I., (2010) Competitiveness and Determinants of Cocoa Export from Nigeria.

[6] Idachaba, F. (1998). Instability of national agricultural Research System in Sub-saharan Africa: lessons from Nigeria. Isnar Research Report 13.

[7] Mafimisebi, T. E., Oguntade, A. E., and Mafimisebi, O. E. (2008) A Perspective of Partial credit Guarantee Schemes in Developing Countries: A Case Study of the Nigerian Agricultural Credit Guarantee Scheme Funds. A paper delivered at The World Bank conference on Partial Credit Guarantee Schemes held at the World
Bank Main Building, Washington, D. C, USA, 1, 15-35.

[8] World Bank (2008) World Bank Development report, 2008. Oxford: Oxford University press.

[9] Omoregbee and Ekpebu, (2012) Adoption rates of improved farm practices among contact and non-contact farmers in Edo state, Nigeria. Nigerian journal of agriculture, food and environment, 8(3), 21-25.

[10] Kassie, M., Zikhali, P., Manjur, K., \& Edwards, S. (2009) Adoption of organic farming technologies: Evidence from semi-arid regions of Ethiopia. Natural Resources Forum, 33, 189-198.http://dx.doi.org/10.1111/j.1477-8947.2009.01224.

[11] Wollni M., D. R. Lee, and L. T. Janice. (2010) Conservation agriculture, organic marketing, and collective action in the Honduran hillsides. Agricultural Economics, 41, 373-384.

[12] Dercon, S., and L. Christiaensen. (2011) Consumption risk, technology adoption and poverty traps: Evidence from Ethiopia. Journal of Development Economics, 96(2), 159-173.

[13] Teklewold, H., Kassie, M. \& Shiferaw, B. (2013) Adoption of multiple sustainable agricultural practices in rural Ethiopia. Journal of Agricultural Economics, 64(3), 597-623. http://dx.doi.org/10.1111/1477-9552.12011

[14] Neill, P. S. and Lee, D. R. (2001) Explaining the adoption and disa doption of sustainable agriculture: The case of cover crops in Northern Honduras. Economic Dev. Cult. Change, 49(4), 793-820.

[15] Oladele, O. I. (2005) A tobit analysis of propensity to discontinue adoption of agricultural technology among farmers in southern Nigeria. J. Central Eur. Agric., 6(3), 249-254.

[16] Aklilu, A. and Graaff de, J. (2007) Determinants of adoption and continued use of stone terraces for soil and water conservation in an Ethiopian highland watershed Ecol. Econ., 61(2-3), 294-302.

[17] An. H. (2008) The adoption and disadoption of recombinant bovine somatotropin in the U. S. dairy industry. Paper presented at the American Agricultural Economics Association Annual Meeting, Orlando, FL, July 27-29.

[18] Doss, C. R. (2006) Analyzing technology adoption using micro studies: Limitations, challenges, and opportunities for improvement. Agricultural Economics, 34(3), 207-219. http://dx.doi.org/10.1111/j.1574-0864.2006.00119.x

[19] Jones, K. M. (2005) Technology Adoption in West Africa: adoption and dis-adoption of soybeans on the Togo-Benin border. (Unpublished MSc thesis), Graduate Faculty of North Carolina State University

[20] Uematsu, H., Mishra, A. K., Roberts, R. K., Lambert, D. M., and English, B. C. (2011) Motivation for Technology Adoption and Its Impact on Abandonment: A Case Study of U. S. Cotton Farmers. Southern Agricultural Economics Association Annual Meeting. Corpus Christi, Texas.

[21] Rogers, E. M. (2003) Diffusion of innovations (5th ed.). In. I. Sahi (Ed.), Detailed review of Rogers' diffusion of innovation theory and educational technology-related studies based on Rogers' theory. The Turkish online journal of Educational technology. TOJET 5(2). New York: Free Press. Greene, W. H. (2003) Econometric analysis. 5th ed. Upper Saddle River, NJ: Prentice-Hall. 
[22] Bamire, A. S., Fabiyi, Y. L., and Manyong, V. M. (2002) Adoption pattern of fertilizer technology among farmers in the ecological zones of South Western Nigeria: a Tobit analysis, Aust J. Agric. Res., 53, 901-910.

[23] Moser, C. M., and Barrett, C. B., (2002) Labor, liquidity, learning, conformity and smallholder technology adoption: The case of SRI in Madagascar. Unpublished manuscript, Cornell University.

[24] Bekele, G. and Mekonnen A. (2010) Investment in land conservation in Ethiopia highlands: a household plot level analysis of the roles of poverty, tenure security, and market incentives. Environment for development, 10(9), 1-41.

[25] Ogundele, O. O. and Okoruwa, V. (2006) 'Technical efficiency differentials in rice production technologies in Nigeria African Economic Research Consortium, Nairobi., 139.

[26] Akinola, A. A and Owombo, P. (2012) Economic Analysis of Adoption of Mulching Technology in Yam Production in Osun State, Nigeria. Journal of Development and Agricultural Economics, 3(10), 492-497.
[27] Owombo, P. T., Akinola, A. A., Ayodele, O. O., and Koledoye, G. F. (2011) Economic Impact of Agricultural Mechanization Adoption: Evidence from Maize Farmers in Ondo State, Nigeria. Journal of Agriculture and Biodiversity Research, 1(2), 25-32.

[28] Odendo, M., Obare, G. and Salasya, B. (2009) Factors responsible for differences in uptake of integrated soil fertility management practices amongst smallholders in western Kenya. Afr. J. Agric. Res., 4(11), 1303-1311.

[29] Akinola, A. A and Owombo, P. (2012) Economic Analysis of Adoption of Mulching Technology in Yam Production in Osun State, Nigeria. Journal of Development and Agricultural Economics, 3(10), 492-497.

[30] Junge, B., Deji, O., Arabio, R., Sikoye, B. and Spahr, K. (2009), Farmers' adoption of soil conservation technology: a case study of Osun state, Nigeria. Journal of agricultural education and Extension, 15(3), 257-274. 